\title{
Lingwizm w poezji współczesnej jako kategoria odbiorcza
}

Zagadnienie, którego dotyczy niniejszy artykuł, skupia w sobie perspektywy językoznawstwa, poetyki oraz teorii wiersza i stanowi jeden z elementów problemu analizowanego kompleksowo przez autora - problemu języka współczesnej poezji. Lingwizm jako kategoria funkcjonuje w oczywisty sposób w związku z tzw. poezją lingwistyczną, rozumianą powszechnie jako kierunek w polskiej poezji po 1956 roku reprezentowany przez indywidua, a wśród nich m.in. Mirona Białoszewskiego, Tymoteusza Karpowicza, Witolda Wirpszę, Edwarda Balcerzana.

Osobność wierszy pisanych przez lingwistów polegała m.in. na eksponowaniu i funkcjonalizowaniu niestandardowych rozwiązań językowych, a przez to na dyskusji z jakością języka codziennego czy potocznej percepcji (często w formie gry lub zabawy). Osiagnięcia mistrzów tego kierunku zapoczątkowały kilka bardzo ważnych procesów niekoniecznie ograniczonych do kwestii czysto literackich. Proponowane w niniejszym tekście spojrzenie jest próbą twórczego odwołania się do poezji lingwistycznej (z wykorzystaniem obecnego stanu wiedzy o języku tekstów poetyckich). Podstawy do tego rozważania mają już pewne poparcie w literaturze przedmiotu.

W jednej z najbardziej inspirujących prac dotyczących teorii wiersza (pisanej przez praktyka) Artur Grabowski stwierdza:

Wzmocnienie intonacyjne i wyodrębnienie słowa w wierszu prowadzi do rozszerzenia się jego pola semantycznego, które nakłada się na inne i w konsekwencji daje okazjonalne, ale mocne zmiany znaczeniowe, te zaś stymulują czytelnicze wyobrażenia. Tak to wersologia dostała się na teren poetyki odbioru ${ }^{1}$.

\footnotetext{
${ }^{1}$ A. Grabowski, Wiersz. Forma i sens, Kraków 1999, s. 24.
} 
W innej ważnej dla tej problematyki pracy Tomasz Kunz pisze:

[...] jednostki poetologicznego opisu uznaję za korelaty chwytów poetyckich o określonej wartości semantycznej, a sam opis za próbę rekonstrukcji mechaniki powstawania znaczeń, która służyć ma ostatecznie zaprojektowaniu swoistej poetyki lektury, zbudowanej w oparciu o wcześniejszą analizę wykorzystanych w tekście strategii semiotycznych².

Intuicja, którą kieruje się autor artykułu wywodzi się zatem zarówno z nienowych już opracowań (Michała Głowińskiego, Janusza Sławińskiego, Stanisława Balbusa), jak i z współczesnych badań podejmowanych na gruncie teorii wiersza, poetyki czy teorii literatury ${ }^{3}$.

Wzięcie pod uwagę lingwizmu jako kategorii odbiorczej wynika pierwotnie z myślenia o poetyce odbioru (wypadnie jeszcze do tego wrócić), wtórnie zaś z inspirujących konkluzji poznańskiej konferencji naukowej („Poezja lingwistyczna. Niedokończony projekt”, Poznań 2006) ${ }^{4}$. Wśród tych ostatnich znalazło się przekonanie (potwierdzone głosem m.in. Krystyny Miłobędzkiej - uznanej za czołową przedstawicielkę tzw. neolingwizmu, oraz Edwarda Balcerzana - poety-lingwisty, a także autora klasycznego tekstu dotyczącego problemu poetyki odbioru), że poeci lingwiści (tu lingwizm rozumiany jako etykieta historycznoliteracka) dokonali przełomu w sposobie traktowania języka w poezji, przełomu polegającego w dużej mierze na wyzyskaniu potencji tkwiącej w tekście poetyckim, ale przecież również na wzmocnieniu wrażliwości czytelniczej przez uświadomienie skomplikowania rozwiązań językowych czy tekstowych.

${ }^{2}$ T. Kunz, Strategie negatywne w poezji Tadeusza Różewicza. Od poetyki tekstu do poetyki lektury, Kraków 2005, s. 8. Autor wprowadza tu pojęcie strategii tekstowej, która: „zawiera w sobie obraz współdziałania tekstowego, którego ośrodkiem pozostają konwencje, mechanizmy i struktury językowe tworzące wypowiedź literacką i umożliwiające jej komunikacyjne funkcjonowanie, ale które nie traci równocześnie z oczu podmiotowego wymiaru komunikacji literackiej, zakładającej znaczeniotwórczą rolę odbiorcy, polegającą nie tylko na aktualizacji sensów zawartych przez autora w wypowiedzi, lecz także na wnoszeniu do nich własnych sposobów rozumienia i nasycania jej własnymi treściami” (s. 12).

${ }^{3}$ Wypada wspomnieć tu także prace dotyczące wiersza współczesnego, m.in.: M. Dłuska, Skrzydta poezji polskiej i wspótczesny nasz antywiersz, w: Studia z historii i teorii wersyfikacji polskiej, t. 2, Warszawa 1978, s. 309-333; A. Kulawik, Wersologia. Studium wiersza, metru i kompozycji wersyfikacyjnej, Kraków 1999; L. Pszczołowska, Wiersz nieregularny, Wrocław 1987; W. Sadowski, Wiersz wolny jako tekst graficzny, Kraków 2004; D. Urbańska, Wiersz wolny. Próba charakterystyki systemowej, Warszawa 1995.

${ }^{4}$ Konferencja naukowa „Polska poezja lingwistyczna. Niedokończony projekt”; organizatorzy: Zakład Poetyki Historycznej Instytutu Filologii Polskiej UAM, Stowarzyszenie Inicjatywa Kulturalna Pro Arte, Poznań 24-27 kwietnia 2006 r. 
Na początku wypada podkreślić, że proponowane tu ujęcie nie podważa istoty poezji lingwistycznej jako takiej - w sensie dobrze przecież oswojonej kategorii porządkującej dzieje literatury polskiej. Wyrażone tu sądy dotyczą współczesnego spojrzenia na lingwizm jako pewną dyspozycję czytelniczą pożądaną przy obcowaniu z poezją najnowszą - zwłaszcza tą która odwołuje się w kwestii formalnej do wiersza nienumerycznego.

Założenie jest zatem takie: współczesna poezja nienumeryczna wymaga specjalnej relacji z czytelnikiem, odbiorca, która to zasadza się na lingwizmie rozumianym jako dyspozycja czytelnicza.

Lingwizm tak pojmowany jest konsekwencją uznania roli komunikacji międzyludzkiej ${ }^{5}$ za czynnik kształtujący lekturę tekstu. Aktywność czytelnicza funduje w tym przypadku potencjalne odczytania ściśle zależne od właściwości języka, w którym powstał tekst. Jeśli przychylać się do przenośni typu: tekst jako partytura, tekst jako kondensacja treści (choćby za sprawą tzw. funkcji poetyckiej), to właśnie kompetencje lingwistyczne (w dużej mierze standardowe) gwarantują pomyślność aktywnej lektury.

Można powiedzieć, że proces odbioru jest jakby powtórzeniem procesu twórczego; w obydwu wypadkach powtarza się droga: od sensów potocznych - do znaczeń wynikających z operacji ściśle poetyckich, od stereotypu świadomościowego - do struktury swoiście literackiej, a także: od chaosu do nadmiaru jednoczesnych uporządkowań przekazu'

Założenie, które dla poetyki odbioru oznacza wpisanie w porządek metodologiczny właściwy poetyce w ogóle, w przypadku postulowanego lingwizmu miałoby dać początek myśli o modelu odbioru dzieła poetyckiego, opartego na konkretnych operacjach językowych. Model taki byłby potwierdzeniem przekonania o tym, że współczesny tekst poetycki jest relacyjną konstrukcją opartą na koincydencji wiersza (układu wersów) i metaforyki ${ }^{7}$. Wszystkie inne zjawiska (rozpatrywane także w duchu poetyki opisowej lub teorii wiersza) mają zakresy wyznaczone ściśle przez tę główną relację. Oznacza to zatem funkcjonalizację wszelkich elementów budowy tekstu, czyli nadmiar rozumiany tu raczej w duchu teorii informacji, a nie jako zbędny ornament.

5 To oczywista inspiracja teoretycznymi ustaleniami E. Balcerzana, którą można by dookreślić: komunikacja międzyludzka, czyli kultura języka rozumiana szeroko jako warunkowana kulturowo norma (także uzualna - zatem nie tylko poprawność). W ten sposób wskazuje się warunki komunikacji literackiej.

6 E. Balcerzan, Perspektywy ,poetyki odbioru”, w: Problemy socjologii literatury, red. J. Sławiński, Wrocław 1971, s. 88.

7 Taki pogląd znalazł szczegółowe omówienie w artykule: K. Skibski, Metaforyzacja a semantyczna potencja wiersza wolnego, „Literaturoznawstwo” 2007, nr 1, s. 227-235. 
Metaforyczna potencja wiersza wolnego opiera się przede wszystkim na wzajemnej relacji momentalnie samodzielnych wersów i szeroko rozumianej kwestii łączliwości. Oba zjawiska sąjuż oczywiście kategoriami specjalnie odbiorczymi (w ścisłym związku jednak z opisanym przez m.in. E. Balcerzana procesem dedykowania tekstu czytelnikowi - jego potocznym, a później profesjonalnym narzędziom odbiorczym). Oto bowiem samodzielność semantyczna wersów to konsekwencja tzw. pierwszej lektury wiersza nienumerycznego, czyli syntagmatyczne wartości poszczególnych członów (czy linijek) tekstu. W tym miejscu warto przypomnieć zarówno problem pauzowania opracowany przez Adama Kulawika ${ }^{8}$, jak i ekwiwalencję postulowaną przez Marię Dłuską ${ }^{9}$. Dotychczasowe koncepcje opisu wiersza wolnego udowadniają bowiem wspólną intuicję - myśl o konieczności uwzględnienia w analizie aktywnego czytelnika. Z kolei łączliwość dotyka kwestii normatywnych, wynika bowiem z założenia, że rozszerzenie kategorialnej łączliwości daje w efekcie wyzwanie semantyczne - innowację domagającą się reakcji czytelniczej. Innowacja taka najczęściej (jeśli nie jest zbytnio ograniczona normatywną refleksją) wywołuje operacje pojęciowe (co w formie miniatury zostanie pokazane poniżej), to z kolei jest potwierdzeniem epistemologicznych wartości metafory. Oczywiście semantyczna samodzielność wersów i łączliwość są współmotywującymi się procesami. Najwyraźniej widoczne jest to w sytuacjach granicznych - na końcach wersów czy na granicach strof (bądź po prostu przed światłem między wersami). Takie zjawiska nazywać można elipsami wersowymi ${ }^{10}$, czyli takimi wersami, które domagają się uzupełnienia (np. w formie koniecznego komponentu frazeologizmu czy argumentu w strukturze predykatowo-argumentowej).

Dla poparcia założeń dotyczących lingwizmu jako dyspozycji czytelniczej warto wspomnieć o kilku zjawiskach ilustrujących zaproponowane ujęcie ${ }^{11}$. Nie wyczerpują one możliwości badawczych, stanowią jedynie podstawę do rozpoczęcia analiz.

${ }^{8}$ Zob. m.in. A. Kulawik, op.cit., s. 55.

9 Zob. m.in. M. Dłuska, Wiersz, w: eadem, Odmiany i dzieje języka polskiego. Prace wybrane, t. 1, Kraków 2001, s. 6 i n.

${ }^{10}$ Zjawisko elips wersowych zostało omówione wstępnie w artykule: K. Skibski, Elipsy wersowe w poezji wspótczesnej - propozycja kategorii, w: Z zagadnień frazeologii, stylistyki $i$ kultury języka, red. S. Bąba, P. Fliciński, Poznań 2006, s. 76-87. Analizy zjawiska elips wersowych dokonano również w pracy: K. Skibski, Antropologia wierszem. Jezzy poetycki Ewy Lipskiej, Poznań 2008.

${ }^{11}$ Zjawiska te domagają się rzetelnego opracowania - w tym miejscu się to tylko sygnalizuje, nie wprowadzając hierarchizacji i dodatkowych charakterystyk. Założenia niniejszego tekstu bowiem stanowią w zamyśle autora wstęp do dalszych badań, ale w ścisłej zgodzie z dotychczasowymi autorskimi próbami analiz języka poetyckiego (np. K. Skibski, Antropologia wierszem...). 


\section{Gramatykalizacja lektury}

Ponieważ założenie funkcjonalizacji wszystkich elementów wiersza, a także przekonanie o fazach jego odczytywania określają rodzaj nadmiarowości w tekście poetyckim, lekturze przyporządkować można proces gramatykalizacji, tzn. kulturowo i lingwistycznie określoną strategię odbioru tekstu poetyckiego według reguł, np.: wiersz wolny składa się z autonomicznych i relacyjnych wersów nie na podstawie dyskredytowania numeryczności (czyli walki z konwencją albo aluzji), tylko na podstawie przyznania tekstotwórczej samodzielności dowolnej, ale świadomie wybranej przez autora jednostce językowej („Forma jest zatem dostępna w konwencjach lektury”12).

$\mathrm{Z}$ takich założeń wynika drugie zjawisko, które przechodzi od tekstologicznych aspektów wiersza do konstrukcji metafory.

\section{Semantyzacja formy wierszowej}

Wiersz jako konstrukcja relacyjnych wersów jest środowiskiem dla konstruowanej metafory - przez tę relacyjność, ale także dzięki zjawisku (procesowi) łączliwości. Semantyzacja może oznaczać lekturę „wersami” (rodzaj statycznej analizy bliskiej w pewnym stopniu poetyce opisowej) oraz późniejszą lekturę wiersza z uwzględnieniem konstrukcji wszystkich elementów (np. efektów elips wersowych czy innych zjawisk i procesów powstałych z relacji międzywersowych).

\section{Epistemologiczna wartość metafory}

Operowanie łączliwością oznaczać może w procesie lektury wyzwanie na poziomie pojęciowym. Wiąże się to zarówno z potocznością rozumianą jako wiedza standardowa użytkowników języka, jak i z możliwościami kategoryzacyjnymi języka wypowiedzi (a także poniekąd z wiedzą specjalistyczną o świecie z perspektywy nauki). Przykładowo: antropomorfizacja, czyli orzekanie o zjawisku niebędącym człowiekiem w kategoriach ludzkich, to typowy mechanizm o wartości epistemologicznej w odbiorze. Oczywiście w strukturze tekstu poetyckiego zderza się taki proces z innymi czynnikami kształtującymi wiersz (co wydatnie komplikuje lekturę). Antropomorfizacja jako problem pojęciowy jest formalnie konsekwencją rozszerzenia łączliwości (np. operowanie diatezą).

\section{Interdyscyplinarność i intertekstualność}

Pierwsza z tych kategorii ma o tyle charakter lingwistyczny, o ile odwołuje się do problemu metodologii, czyli także języka opisu (np. konstrukcja zaczerp-

\footnotetext{
${ }^{12}$ A. Grabowski, op.cit., s. 24.
} 
nięta z wypowiedzi humanisty: Kultura chciałaby w tym miejscu widzieć... jest kłopotem kategorialnym dla fizyka) i nie sprowadza się wyłącznie do kwestii terminologicznych. Intertekstualność zaś to m.in. stopniowalne kompetencje odbiorcze czytelnika, z obecnym także aspektem lingwistycznym: oto np. modyfikacja frazeologizmu czy aluzja do konstrukcji metaforycznej może wzbogacać lekturę, ale brak świadomości zabiegów nie musi uniemożliwiać odczytania w ogóle.

Za prostą ilustrację opisanego wstępnie lingwizmu jako kategorii odbiorczej niech posłuży próba analizy zjawiska paralelizmu jako tworzywa elipsy wersowej. Przykład ten, choć oczywiście nie ukazuje wszystkich problemów i wyzwań, wydaje się przydatny ze względu na to, że dotyczy zarówno strategii odbioru tekstu nienumerycznego, jak i - szczegółowo - relacji metaforyki i wersów oraz łączliwości.

Zjawisko paralelizmu wersowego wpisuje się oczywiście w tradycję badań nad językiem tekstów artystycznych, jednak stanowić może rodzaj wyzwania ze względu na postulowaną wieloczynnikowość charakterystyczną dla wiersza współczesnego. Oto bowiem (przy niewątpliwych walorach stylistycznych ${ }^{13}$ ) paralelizm może funkcjonować jako czynnik metaforyzacyjny w wierszu; jako podstawa tzw. zmąconej powtarzalności.

\section{Paralelizm tekstowy}

Uznając relacyjność wersową jako konstytuantę wiersza oraz przyjmując elipsę wersową jako mechanizm koniecznego uzupełnienia syntagm doraźnych, można wskazać takie sytuacje tekstowe, w których sugerowana paralelna konstrukcja językowa (wyrażenie, fraza) jednocześnie wyzyskuje domniemaną tożsamość formalną i przekształcenie. To zjawisko można zauważyć np. w wierszu J. Ekiera wczoraj:

\section{kto mógł przed nocą wrócil do siebie nie oglądając się na to ziemiste miasto kramy w sercu ani sklepy z blaskiem znieruchomiałe schody ślad $\mathrm{w}$ asfalcie ani alarmy aut kto mógł przed nocą wrócil do domu wioząc pełny albo pusty dzień}

${ }^{13}$ W tym miejscu należy wspomnieć o kwestii różnej jakości odwołań do tradycji genologicznej - niektórzy autorzy realizują określone wzorce gatunkowe, inni natomiast wyzyskują aluzje do gatunków, wciąż jednak uznając wzorzec za podstawę (choćby polemicznie) tekstu. 
kto mógł zasnął

śnił

w pokoju ${ }^{14}$.

Narracyjność tego wiersza jest modyfikowana brakiem delimitacji interpunkcyjno-ortograficznej. Wzmocniona relacyjność wersów motywowana jest przez wariantywną łączliwość, to zaś konstruuje efekt elipsy wersowej i rozbudowuje przestrzeń sensów. Przeciwwagą dla takiego rozwiązania jest niewątpliwie hermetyczność tekstu. Dopiero w konfrontacji tych dwu właściwości rysuje się perspektywa jego odczytania.

Pierwszy wers umożliwia dwutorową lekturę przez wzgląd na znaczenie konstrukcji wrócić do siebie. Potoczne określenie powrotu do domu (do miejsca, w którym się mieszka) nakłada się na aluzję przenośnego rozumienia - 'odzyskać równowagę, otrząsnąć się z czego, zregenerować siły, wyzdrowieć'. Taka dwoistość motywuje ponowne odczytanie tekstu z przywołaniem zarysowanej paraleli. Po wyliczeniu elementów związanych z pozostawianym miastem następuje znów fraza kto mógt wrócił/ do domu, która dzięki zastosowaniu mechanizmu elipsy uruchamia dodatkowe procesy znaczeniotwórcze. Znaczący brak interpunkcji uprawomocnia eksponowanie komponentu wrócił (kto? - ten, kto mógł), jednak przede wszystkim przywołuje na prawach paraleli dopowiedzenie do siebie. Uzupełnienie okazuje się precyzowaniem znaczenia pierwszej frazy: do domu, to jedno z możliwych odczytań wyrażenia do siebie. Niesprzeczne jednak także wydaje się połączenie do domu wiozqc, przez co w inny sposób rozbudowuje się równoległa, choć członowana fraza.

Ostatnie trzy wersy tekstu rozpoczynające się paralelizmem kto mógl przywołują niejednoznaczność sygnalizowaną na początku tekstu. Konstrukcja zasnać, śnić w pokoju może funkcjonować jako zwieńczenie opisu wieczornego powrotu do domu, który kontrastuje wówczas jedynie z położeniem tych, co nie powrócili (kto mógt). Jednakże ta druga sytuacja staje się możliwa jako immanentny układ sensów w wierszu. Zasnać i śnić w pokoju to także umrzeć, czyli nie wrócić do siebie w obu możliwych znaczeniach. Koniec dnia wczorajszego okazuje się w takiej lekcji dwuznaczny, jak dwuznacznie zaczynają funkcjonować wszystkie elementy opisu w tekście. Zostawienie czegoś (dnia, miasta, życia) poza sobą staje się stopniowalne na prawach tekstowej metafory, która uaktywnia wewnętrzne, implikowane porządki czytania.

W przywołanym tekście sensy motywowane są między innymi przez wyzyskanie paralelizmu, ale w ścisłej zależności od członowania tekstu (tylko

${ }^{14}$ J. Ekier, wczoraj, w: idem, podczas ciebie, Kraków 1999, s. 22. 
wersowego przy braku interpunkcji). Powstaje zatem elipsa, której konieczność uzupełnienia określa wcześniejsze użycie przedzielonej frazy.

Odmienną sytuację zaobserwować można w tekstach częściowo regularnych, w których paralelizm układu wierszowego dookreśla relacje sensów.

rozmawiam z twoją śmiercią (skoro

tylko tyle mogę) o mojej śmierci

odkąd mam jej numer telefonu w notesie

i dzwonię ażeby zagadnąć o ciebie

myślę o twoim życiu które dobiegło dwudziestu

paru lat aby cieszyć się wonnością

odkąd mam jej telefon jestem spokojniejszy

o to czy cię usłyszę zobaczę obejmę

zatem myślę o twoim życiu które tutaj nigdy

nie było wonnością ani nie jest tym czym

jest gdzie indziej odkąd dzwonię ażeby zapytać

co porabiasz i co ja mam ze sobą zrobić ${ }^{15}$.

Wiersz Eugeniusza Tkaczyszyna-Dyckiego to dramatyczne świadectwo rozpisanej na wersy rozmowy-implikacji, próby odtworzenia dialogu z martwej ciszy. Tekst stanowi kunsztowny przykład na relacyjność wiersza po części numerycznego, frazą jednak (pozbawioną interpunkcji i ortografii) bliskiego prozie. Ułożenie wersów w trzy kwadryny funkcjonuje tutaj między innymi jako etykieta odsyłająca do specjalnej strategii odczytania. Za każdym razem rozpoczynana pozornie myśl wyprowadzona zostaje z poprzedniej (strofy), co tworzy układ rozkwitający, ale nieregularny semantycznie, jedynie formalnie podobny do siebie. Struktura pierwszej strofy, dzięki zwrotowi podmiotu oraz aktywnym implikacjom semantycznym, wskazuje na cztery postaci: dwie osoby i ich osobne śmierci. Już inicjalny wers z rozdzieloną parentezą kreśli prymarną sytuację podmiotową. Rozmowa z czyjąś śmiercią sygnuje ponury układ deiktyczny: ktoś umarł, z kimś nie można już nawiązać bezpośredniego kontaktu. Parenteza dopowiada, że taka próba porozumienia z nieobecną osobą - przez śmierć - jest jedyną możliwą. Następujące w drugim wersie dopowiedzenie: $z$ moja śmiercia, otwiera pełne, od tego momentu aktywne, spektrum wewnętrznych relacji osobowych w tekście. Osobność podmiotu i nieobecnej postaci nie jest tożsama ze spójnością indywidualnych śmierci.

15 E. Tkaczyszyn-Dycki, CXVI. Bezczynność, w: idem, Przewodnik dla ludzi bezdomnych niezależnie od miejsca zamieszkania, Legnica 2000, s. 136. 
Taką konstatację uprawomocnia funkcja wersu trzeciego odkad mam jej numer telefonu w notesie. Otóż dzięki dwojakiej łączliwości za pośrednictwem zaimka jej klarują się dwie koncepcje odczytania (uznawane za równoważne). Numer do czyjejś śmierci stanowi próbę (konieczność) zapośredniczonego kontaktu, numer do własnej śmierci zaś oznacza memento, które przy tym także jest potencjalnością nawiązania kontaktu z kimś nieżyjącym.

Gęsta sieć implikacji zawarta w pierwszej strofie organizuje sensy także w dalszym ciagu tekstu. Pierwszy wers drugiej strofy wprowadza w podmiotowej perspektywie kategorię retrospektywną twoje życie. Parafraza trzeciego wersu pierwszej strofy odkqd mam jej telefon znów odsyła do dwutorowego odczytania metonimii (telefon - czyjś numer telefonu), co uzupełnia semantykę całej strofy. W konsekwencji takiego przeplatania znaczeń bowiem ostatni wers funduje osobliwy paradoks. Jeśli numer odsyła do nieswojej śmierci, to „spokój” podmiotu tłumaczyć można dramatyczną pewnością, że nie da się nigdy już zmarłej osoby usłyszeć zobaczyć objać. Jeśli zaś numer stanowi memento - pierwsze rozumienie okazuje się podane w wattpliwość.

Występujący w ostatniej strofie paralelizm wersowy dzwonięażeby zapytać można uznać za intensyfikację wcześniej opisywanego napięcia, przygnębiającej i pełnej dramatycznych myśli bezczynności. Przez dopowiedzenie w ostatnim wersie następuje redukcja do relacji ja - ty, wyrażona ponadto dwoma, pozornie banalnymi frazemami. Konstrukcja co porabiasz, jako przynależna rzeczywistej rozmowie (telefonicznej), zdaje się elementem neutralnej komunikacji, która jednak przez dopowiedzenie co ja mam ze sobq zrobić eksponuje dramatyczną rozbieżność dwu sytuacji.

Tytułowa bezczynność w wierszu bliska jest bezradności. Wewnętrzna dynamika podmiotowej wypowiedzi, osobliwa gęstość języka wskazują na intensywny ruch myśli. Dzwonienie donikąd po nic jest esencją bezczynności, której towarzyszy tylko intencja, wewnętrznie niejednorodna, popierana zmienną emocją, rodząca polemiki wewnątrz podmiotu. Tematyczne gęstnienie tekstu, m.in. przez paralelny ciag: odkqd mam jej numer telefonu, odkqd mam jej telefon, odkqd dzwonię oraz brak interpunkcyjnej i ortograficznej delimitacji, stanowi świadectwo pustki, z której rodzi się chęć wykreowania absurdalnego polilogu (przez śmierci). Eliptyczność paralelizmu jest tu bardzo kunsztowna - redukuje (tnie) podmiotową perspektywę (czyli ingeruje znacznie w semantykę), jednocześnie wzmacniając wyrażenie emocji w tekście.

\section{Paralelizm intertekstualny - hipoteza}

Niesprzeczne wydaje się przekonanie, że konstrukcja paralelna nie musi dotyczyć jednego tekstu, może bowiem wykorzystywać zjawisko intertekstualności rozumianej nie ściśle jako funkcjonalne cytowanie, ale jako inter- 
akcyjne skojarzenie tekstów lub ich fragmentów. Wówczas elipsa wersowa może być zbudowana na podstawie dobrze utrwalonego (bądź sugestywnie przywołanego) fragmentu tekstu. Wykorzystany fragment o tyle nie jest tylko aluzja, o ile daje się rekonstruować do tzw. postaci kanonicznej na podstawie kilku wiernie zacytowanych elementów. Mechanizm taki byłby poniekąd bliski elipsie opartej na frazeologizmie, z tą jednak różnica, że po pierwsze fragmenty paralelizmów intertekstualnych mają swoje konkretne źródło tekstowe (lub autora), po drugie - nie muszą być konstrukcjami o nieregularnym znaczeniu (jako jednostka językowa). Niniejsze wskazanie ma charakter rozpoznań wstępnych, jednak we wprowadzeniu do przyszłych analiz warto także przypomnieć, że możliwa jest tego typu intertekstualność w obrębie tekstów jednego autora (np. cykl u E. Tkaczyszyna-Dyckiego czy parafraza autocytatu u Tadeusza Różewicza) lub z wykorzystaniem innych tekstów kultury (np. arcydzieł literatury lub Biblii) ${ }^{16}$.

\author{
susza taka że \\ rdzewieją jałowce \\ krzyk bezgłośnie w nią wsiąka \\ nawet modlitwa o deszcz \\ zapomina się \\ aż do milczenia \\ liść miał cofnąc się w pąk \\ albo wyrosnać \\ i nie zdążył \\ a słowo stało się \\ tak niedosłowne \\ jak kamień uduszony trwaniem \\ bez dopływu czasu \\ bo czas odpłynął \\ śladem er i epok \\ swym suchym nurtem \\ przez puste łożyska ${ }^{17}$.
}

16 Specjalnym przykładem paralelizmów wersowych byłoby wykorzystywanie, zwłaszcza w tekstach poetów Nowej Fali, określonych szablonów językowych (np. zaczerpniętych z nowomowy) jako podstawy dla mechanizmów metaforyzacyjnych (np. teksty S. Barańczaka czy R. Krynickiego).

17 J. Ficowski, Rdzewieja jałowce, w: idem, Pantareja, Kraków 2006, s. 22. 
Niniejszy artykuł rozpoczyna się propozycją rozważenia lingwizmu jako kategorii odbiorczej, a zmierza do badań nad modelem lingwistycznego odbioru wiersza (LOW). Lingwizm, będący pierwotnie określeniem nurtu w poezji, przyczynił się do rozwoju refleksji nad wierszem nienumerycznym, nad konstrukcją i możliwościami wiersza w ogóle (także wiersza jako sposobu lektury). Eksploatowanie języka przez poetów lingwistów (dziś właściwie klasyków) umożliwiło specjalizację w postaci neolingwizmu, głównie za sprawą tego, że od czytelnika wymaga się lingwistycznych dyspozycji (versus: czytelnik przekonał się o konieczności lingwistycznego odbioru tekstów poetyckich). Dlatego też skojarzone perspektywy poezji, teorii wiersza, poetyki i językoznawstwa mogą posłużyć za podstawę modelu odbioru, uwzględniającego bogactwo konstrukcyjne poezji współczesnej, ale także (w wersji podstawowej) mogą być niejednokrotnie czynnikiem wzmacniającym przekonanie o pięknie zawartym w tych nierzadko pozornie nieprzystępnych tekstach.

\section{Krzysztof Skibski}

\section{Linguism in Modern Poetry as a Reception Category}

The article offers a proposal for the studies into a particular receptive disposition (derived from the phenomenon of Polish linguistic poetry) as a consequence of recognition of the special structure of a modern poem. The poetics of reception, rooted in theoretical tradition, when juxtaposed with reflection on the structure of verse and in connection with an epistemological value of a metaphor (as a notional construct) may motivate methodological (linguistic) considerations focused on language fundamentals for the reception of poetic texts.

Apart from the general presentation of the topic, the article also includes an analytical sample, which deals with the phenomenon of parallelism in modern poetry. This parallelism is an effect of ellipsis in the verse, created in close connection with the poem's construction and the reader's reception competence. 
